\title{
Anti-inflammatory Activity of Ethanol Extract from Malacca Leaves (Phyllanthus emblica) in Carrageenan Induced Male Mice
}

\author{
Nuzul Asmilia ${ }^{1 *}$, Amalia Sutriana ${ }^{2}$, Dwinna Aliza ${ }^{3}$, and Nurfadilla Sudril ${ }^{4}$ \\ ${ }^{1}$ Clinical Laboratory Veterinary Medicine Universitas Syiah Kuala, Banda Aceh 23111, Indonesia \\ 2 Farmacology Laboratory Universitas Syiah Kuala, Banda Aceh 23111, Indonesia \\ ${ }^{3}$ Patology Laboratory Universitas Syiah Kuala, Banda Aceh 23111, Indonesia \\ ${ }^{4}$ Veterinary Study Program, Faculty of Veterinary Medicine Universitas Syiah Kuala, Banda Aceh 23111, Indonesia
}

\begin{abstract}
The purpose of this study was to determine the effect of the ethanol extract of malacca leaves (Phyllanthus emblica) to reduce carrageenan-induced edema in mice. This study used 25 mice which were divided into 5 groups with 5 mice per group. All the mice were induced inflammation using carrageenan at a dose of $1 \%$. Mice in group 1 were not given piroxicam and malacca leaves extract. Mice in group 2 were treated with $20 \mathrm{mg}$ of piroxicam suspension. Mice in groups 3, 4, and 5 were given ethanol extract of malacca leaves with doses of $100 \mathrm{mg} / \mathrm{kg} \mathrm{bb}, 200 \mathrm{mg} / \mathrm{kg} \mathrm{bb}$, and $300 \mathrm{mg} / \mathrm{kg} \mathrm{bb}$, respectively. Edema volume measurements were performed on 5th day by collecting exudates using a syringe. Data were analyzed using one-way analysis of variance and continued with the Duncan test. The result showed that the average of edema volume in the negative control group was $0.09 \pm 0.02 \mathrm{~mL}$, while in the positive control group was $0.05 \pm 0.03$ $\mathrm{mL}$. The average edema volume in groups 3 , 4 , dan 5 were $0.07 \pm 0.01 \mathrm{~mL}, 0.06 \pm 0.02 \mathrm{~mL}$ dan $0.07 \pm 0.01$ $\mathrm{mL}$, respectively. It is concluded that the ethanol extract of malacca leaves (Phyllanthus emblica) can reduce the carrageenan-induced edema in male mice.
\end{abstract}

Keywords: malacca leaves, carrageenan, ethanol, anti-inflammatory.

\section{Introduction}

Inflammation is a local protective process caused by injury or tissue damage, which destroy and reduce the number of microorganisms that cause infection or tissue damaged by injury. The inflammatory process involves various process can be caused by stimuli such as the invasion of pathogenic microorganisms, ischemia, antibody-antigen interactions, as well as exposure to heat or other physical injuries [1].

The inflammatory response is characterized by conditions in the form of rubor (redness), heat (heat), dolor (pain), tumor (swelling) and impaired function. Inflammation can be local and systemic, it can also occur acutely or chronically which causes pathological abnormalities. Inflammatory treatment includes two aspects, the first is relief of pain that is often a symptom and the second is an effort to stop the process of tissue damage. Reducing inflammation of the inflammatory response using steroid drugs and non-steroidal antiinflammatory drugs (NSAIDs) can relieve inflammatory reactions well but long-term use can have side effects. Side effects include decreased endogenous glucocorticoid synthesis, the body's immune response to infection, osteoporosis, moon face, and hypertension. The use of systemic non-steroidal anti-inflammatory drugs
(NSAIDs) in the long term can also have side effects in the form of gastrointestinal disorders such as peptic ulcers, neuropathic analgesics, disrupt platelet function and inhibit pregnancy induction [2].

Nowadays, people's interest in natural medicine is increasing. The use of plants as medicines and other purposes has become a phenomenon nowadays. Research on pharmacological and phytochemical aspects derived from plants that have been used by the community as medicine is growing. In developing countries, many traditional plants are used as anti-inflammatory and antipyretic [3], one of which is a malacca plant [4].

Malacca (Phyllanthus emblica) is a plant that has many benefits such as treating diabetes, as an analgesic, hepatoprotective, antipyretic, anti-inflammatory, anticancer, antihyperlipidemic, and antidiarrheal [5]. The results of phytochemical isolation in the fruits and leaves of malacca conducted by [6] showed that the plant contained several chemical compounds including alkaloids, flavonoids, saponins, tannins, terpenoids, glyceroids, benzenoids, phenolics, lignins, furanolactones, triterpenes, carbohydrates, and fat. Malacca tissue culture also contains alkaloids and at the root contains polyphenols and flavonoids [3]. Flavonoid compounds can function as an anti-inflammatory by inhibiting the enzymes cyclooxygenase and 
lipooksigenase can provide hope for the treatment of symptoms of inflammation and allergies [7].

So far, scientific data regarding the antiinflammatory activity of ethanol extract of malacca leaves (Phyllanthus emblica) is not available, therefore it is necessary to study the anti-inflammatory activity of ethanol extract of malacca leaves in male mice induced by carrageenan in terms of edema volume reduction. The purpose of this study was to determine the effect of ethanol extract of malacca (Phyllanthus emblica) leaves on edema volume reduction in carrageenan-induced mice.

\section{Materials and Methods}

\subsection{Preparation of experimental animals}

The experimental animals used in this study were 25 male mice (Mus Musculus) aged 3 months and weighed 25-30 grams, which were declared clinically healthy and induced inflammation using carrageenan suspension. Mice were obtained from the Pharmacology Laboratory of Faculty of Veterinary Medicine, Syiah Kuala University, Banda Aceh. Before conducting the study, all mice were acclimatized for 1 week. A total of 25 male mice were randomly selected and allocated in 5 different cages (5 mice per cage) which equipped with litter. During the experiment, the mice were provided with pellets and water ad libitum.

\subsection{Extraction of malacca leaves}

Malacca leaf was obtained from Aceh Besar The leaf samples were cleaned and air dried, grinded to powder form, and sieved with a size of 40 mesh. Malacca leaf powder was macerated using $70 \%$ ethanol solvent for 72 hours until the solution was clear. Maceration results were filtered using filter paper. The filtrate obtained was collected and evaporated using a vacuum rotary evaporator equipped with a water bath and vacuum pump until all the solvents evaporated and the extract was obtained in the paste form.

\subsection{Induction of inflammation}

Inflammation in mice was induced according to the method carried out by [8] as follows:

a. Before treatment, the hair from the dorsum of mice was removed using a razor and left for 24 hours. The shaved area was then injected with $5 \mathrm{ml}$ air subcutaneously to create the air pouch and also injected $0.05 \mathrm{ml}$ of $1 \%$ carrageenan in physiological $\mathrm{NaCl}$.

b. After 24 hours the air pouch formed was suctioned with a $5 \mathrm{ml}$ syringe, so that the air pouch became deflated, then added with $0.1 \mathrm{ml}$ of $1 \%$ carrageenan solution in physiological $\mathrm{NaCl}$.

\subsection{The administration of malacca leaves extract}

Immediately after the induction of inflammation, the mice were given malacca leaves extract for 4 days in each group. Mice in group 1 (negative control) were not treated. Mice in group 2 (positive control) were given 20 $\mathrm{mg}$ piroxicam suspension. Mice in groups 3, 4, and 5 were given ethanol extract of malacca leaves respectively at a dose of $100 \mathrm{mg} / \mathrm{kg}$ body weight, $200 \mathrm{mg} / \mathrm{kg}$ body weight and $300 \mathrm{mg} / \mathrm{kg}$ body weight. Inflammation volume measurements were carried out on the 5th day. The exudate was collected from air pouch using a syringe and the exudate volume was measured.

\subsection{Data analysis}

Data were analyzed using a one-way analysis of variance (ANOVA).

\section{Results and Discussion}

Extraction is a process that aims to separate the desired components from a plant to obtain active compounds with high purity. Several factors affect the extraction process, including the type of solvent, the ratio of the solvent to the extraction material, temperature, pressure and extraction time as well as the bioactive components of the plant $[9,10]$.

The results of edema volume measurements that have been performed on male white mice induced by $1 \%$ carrageenan were presented in Table 1.

Table 1. The volume of edema in male white mice in different treatment group (Mean \pm SD)

\begin{tabular}{ll}
\hline Groups & $\begin{array}{l}\text { Exudate } \\
\text { Volumes }(\mathrm{mL})\end{array}$ \\
\hline Group 1 (control negative) & $0,09 \pm 0,02^{\mathrm{b}}$ \\
Group 2 (control positive) & $0,05 \pm 0,03^{\mathrm{a}}$ \\
Group 3 (Dose 100 mg/ KgBB) & $0,07 \pm 0,01^{\mathrm{a}}$ \\
Group 4 (Dose 200 mg/ KgBB) & $0,06 \pm 0,02^{\mathrm{a}}$ \\
Group 5 (Dose 300 mg/KgBB) & $0,06 \pm 0,01^{\mathrm{a}}$
\end{tabular}

$\overline{\mathrm{a}, \mathrm{b}}$ Different superscripts in the same column showed significant differences $(\mathrm{P}<0.05)$

The results showed that the mean $( \pm \mathrm{SD})$ edema volume in the negative control group was $0.09 \pm 0.02 \mathrm{~mL}$, while in the positive control group was $0.05 \pm 0.03 \mathrm{~mL}$. The average edema volume in groups 3,4 , and 5 were $0.07 \pm 0.01 \mathrm{~mL} 0.06 \pm 0.02 \mathrm{~mL}$, and $0.06 \pm 0.01 \mathrm{~mL}$, respectively. Statistically, the administration of ethanol extract of malacca leaves significantly affect the volume of edema ( $\mathrm{P}<0.05)$. The edema volume in mice treated with malacca leaves extract with different doses were reduced significantly compared to mice in negative control group, but the value was similar $(\mathrm{P}>0.05)$ compared to the positive control group (piroxicam administration).

Inflammation with carrageenan induction is an acute inflammatory method that can stimulate the release of prostaglandins, histamine, and serotonin [11]. When the cell membrane is damaged, phospholipids are converted to arachidonic acid catalyzed by phospholipase. Arachidonic acid will then be metabolized by lipooksigenase and cyclooxygenase and in cyclooxygenase pathway, the prostaglandins are synthesized. Prostaglandins can increase the blood flow to inflamed areas, increase capillary permeability and stimulate pain receptors. The increasing of permeability 
and vasodilation causes fluid in blood vessels flows to the site of injury, which create the edema.

The decrease in edema volume in carrageenaninduced mice was probably influenced by the presence of flavonoids compound in malacca leaves. The antiinflammatory mechanism carried out by flavonoids is by inhibiting the activity of the cyclooxygenase and lipooksigenase enzymes which can directly inhibit the biosynthesis of prostaglandins and leukotrienes which are the end products of the cyclooxygenase and lipooksigenase pathways. Indirectly, the inflammation inhibition contribut to the inhibition of accumulation of leukocytes in the inflammation area [8].

\section{Conclusion}

The ethanol extract of malacca (Phyllanthus emblica) leaves can reduce the volume of edema in carrageenaninduced white male mice.

\section{References}

1. Anggraeny EN, Pramitaningastuti AS: Studi uji daya antiinflamasi dan antipiretik ekstrak etanol daun lengkeng (Dimocarpus longan Lour) pada tikus putih jantan (Rattus norvegicus) galur wistar. JIF. 2016; 12(2): 44-51.

2. Sukmawati, Yuliet, Hardan R: Uji aktivitas antiinflamasi ekstrak etanol daun pisang ambon (Musa paradisiaca L.) terhadap tikus putih (Rattus norvegicus $\mathrm{L}$.) yang diinduksi karagenan. GALENIKA J. Pharm. 2015; 1(2) : 126-132.
3. Summanen JO : A chemical and ethnopharmalogical study on Phyllanthus emblica (Euphorbiaceae). Disertasi. Department of Pharmacy Division of Pharmacognosy, University of Helsinki. Finland. 1999.

4. Baliga MS, Dsouza JJ: Amla (Emblica officinallis Gaertn), a wonder berry in the treatment and prevention of cancer. Eur. J. Cancer Prev. 2011;20(3): 225-239.

5. Kaur J, Kaur D, Singh H, et al. : Emblica officinalis: a meritocratic drug for treating various disorders. Indo American J. Pharm. Res. 2013; 3(6): 4477-4496.

6. Dhale DA, Mogle UP : Phytochemical screening and antibacterial activity of Phyllanthus emblica (L.). Sci. Res. Rep. 2011; 1(3): 138-142.

7. Hidayati NA, Listyawati S, Setyawan AD : Kandungan kimia dan uji antiinflamasi ekstrak etanol Lantana camara L. pada tikus putih (Rattus norvegicus L.) jantan. Bioteknologi. 2008; 5 (1): 10-17.

8. Aria M, Verawati, Arel A, et al. : Uji efek antiinflamasi fraksi daun piladang (Solenostemons cutellarioides $(\mathbf{L}$. Codd) terhadap mencit putih betina. SCIENTIA. 2015; 5(2): 84-91.

9. Lopez A, Rico M, Rivero A: : The effects of solvents on the phenolic contents and antioxidant activity of Stypocaulon scoparium algae extracts. Food Chem. 2011; 125(3): 1104-1109.

10. Hidayah N, Hisan AK, Solikin A, et al. : Uji efektifitas ekstrak Sargassum muticum sebagai alternatif obat bisul akibat aktivitas Staphylococcus aureus. Journal of Creativity Students. 2016; 1(1): 1-9.

11. Morris CJ : Carrageenan-Induced Paw Edema in the Rat and Mouse. Methods Mol Biol. 2003. 